\title{
The regulation of interferon- $\tau$ production and uterine hormone receptors during early pregnancy
}

\author{
G. E. Mann ${ }^{1}$, G. E. Lamming ${ }^{1}$, R. S. Robinson ${ }^{2}$ \\ and D. C. Wathes ${ }^{2}$ \\ 'University of Nottingham, School of Biological Sciences, Division of Animal Physiology, \\ Sutton Bonington, Loughborough, Leics LE12 5RD, UK, ${ }^{2}$ Department of Veterinary Basic Sciences, \\ Royal Veterinary College, Boltons Park, Hawkshead Road, Potters Bar, Herts EN6 1NB, UK
}

\begin{abstract}
During early pregnancy the bovine embryo must produce a protein called interferon $\tau$ which inhibits the development of the luteolytic mechanism. Failure to inhibit luteolysis is the major cause of pregnancy loss in cows. The embryo must produce sufficient quantities of interferon $\tau$ by about day 16 to prevent luteolysis. Its ability to achieve this is largely dependent on the pattern of maternal progesterone production. A late rise in progesterone after ovulation or poor progesterone secretion during the luteal phase results in the development of poor embryos capable of producing little or no interferon $\tau$ at the critical time. The embryo inhibits luteolysis by preventing development of oxytocin receptors on the luminal epithelium of the uterine endometrium and thus oxytocin-induced secretion of $\mathrm{PGF}_{3 a}$ and by the induction of a prostaglandin synthesis inhibitor within the endometrium. In sheep it has been hypothesised that interferon $\tau$ acts to inhibit endometrial oestrogen receptors and thus oestrogen-induced upregulation of oxytocin receptors. In cows, the embryo inhibits the development of oxytocin receptors and the initiation of luteolysis without causing any change in uterine oestrogen receptors. Thus in the cow, the mechanism by which interferon $\tau$ inhibits oxytocin receptor development remains to be determined.
\end{abstract}

\section{Introduction}

Compared with the high level of fertility observed in several species of wild ungulates, pregnancy rates in domestic cattle are currently very low, and appear to be declining. While poor fertility is the result of a number of factors, probably the biggest single cause of poor fertility in cattle is early embryo mortality. For its continued development during early pregnancy, the embryo must prevent the demise of the corpus luteum and thus maintain the secretion of progesterone. To do this it must inhibit the development of the luteolytic mechanism that terminates the luteal phase of the oestrous cycle. Luteolysis results from the release of luteolytic episodes of uterine prostaglandin $\mathrm{F}_{2 u}\left(\mathrm{PGF}_{2 u}\right)$. The majority of current evidence suggests that this occurs in response to the binding of oxytocin to newly developed receptors on the uterine endometrium. The embryo inhibits luteolysis through the secretion of interferon $\tau$, which acts locally within the uterus to inhibit both the development of oxytocin receptors on the endometrium and the secretion of $\mathrm{PGF}_{21}$. Thus the success of early pregnancy in cows, as in other ruminant species, depends upon a fine balance between the development of a maternal luteolytic mechanism and an antiluteolytic embryonic signal. A strong or early signal from the mother for the corpus luteum to regress or a weak or delayed signal from the embryo to prevent the loss of the corpus luteum results in the failure of the pregnancy. Why this balance so often fails has been the focus of much study in recent years. 


\section{Hormonal Influences on the Outcome of Early Pregnancy}

Many of the mechanisms involved in early pregnancy are influenced by the ovarian steroid hormones, progesterone and oestradiol, and many studies have investigated their roles. A common approach has been to monitor concentrations of hormone in mated cows and then retrospectively analyse these profiles on the basis of whether the animals successfully maintained a pregnancy. It has been established for many years that the concentration of progesterone during early pregnancy has a marked effect on the potential outcome. Lower concentrations of plasma progesterone from about day 12 after mating have been reported in animals in which early pregnancy fails in a number of studies (Lukazewska and Hansel, 1980; Lamming et al., 1989; Mann et al., 1995; Fig. 1). Reanalysis of the data of Mann et al. (1995) has revealed that as well as an original difference in milk progesterone between day 12 and day 15 , there is also a significantly lower milk progesterone concentration on day 6 in mated not pregnant cows compared with pregnant cows (Fig. 1). A lower concentration of progesterone 6 days after mating in cows with a failed pregnancy was reported in 1971 by Henricks et al., while more recently Lamming and Darwash (1995) reported that a progressive delay in the post-ovulatory rise in progesterone was associated with a marked and progressive reduction in pregnancy rate in mated animals. These studies clearly demonstrate that both a late post-ovulatory rise in progesterone and low luteal phase concentrations of progesterone have a detrimental effect on the outcome of early pregnancy.

Although oestradiol concentrations have not been studied as comprehensively as concentrations of progesterone during early pregnancy, most studies indicate that concentrations of oestradiol do not differ between mated cows in which pregnancy is successful or fails (Lukaszewska and Hansel, 1980; Gyawa and Pope, 1992; Mann et al., 1995). In one study in beef cows by Pritchard et al. (1994), a lower pregnancy rate was observed in cows with higher plasma concentrations of oestradiol between day 14 and day 17. However, in this study, luteolysis had begun in some cows and so it is not clear whether the higher concentration of oestradiol was the cause of pregnancy failure or the result of failed embryonic inhibition of luteolysis. Thus current evidence supports the idea that oestradiol does not exert the same degree of influence as progesterone over the outcome of early pregnancy.

Although these studies identify the importance of the concentration of progesterone during early pregnancy, they do not answer the question of how progesterone is exerting its effects. To establish this we must look at the effects of progesterone on the important mechanisms in place during this period. For example, it has now been demonstrated that the concentration of luteal phase progesterone in the cow has a profound influence on the strength of development of the luteolytic signal (Mann and Lamming, 1995a). Furthermore, although oestradiol concentrations do not differ between pregnant and non-pregnant cows, studies have demonstrated an important influence of the concentration of oestradiol in controlling the strength of the luteolytic signal (Mann and Lamming, 1995b).

\section{Production of Interferon $\tau$ - The Embryonic Signal}

\section{Identification of the anti-luteolytic agent}

In 1966, Moor and Rowson established, in sheep, that the presence of an embryo first affected luteal function on day 13 after mating, and Rowson and Moor (1967) found that infusion of homogenates of day 13 and 14 embryos into the uteri of cyclic ewes prolonged luteal life span. This established both the importance of the embryo in the inhibition of luteolysis and the time at which this effect takes place. In cows, Northey and French (1980) demonstrated that removal of the embryo from the uterus on day 15 does not result in a delay in luteolysis, whereas removal on day 17 results in a significant delay. Furthermore, infusion of homogenates of day 17-18 embryos resulted in a delay in luteolysis. Thus it was established that the embryo exerted an anti-luteolytic effect on the cow between day 15 and day 17 . 


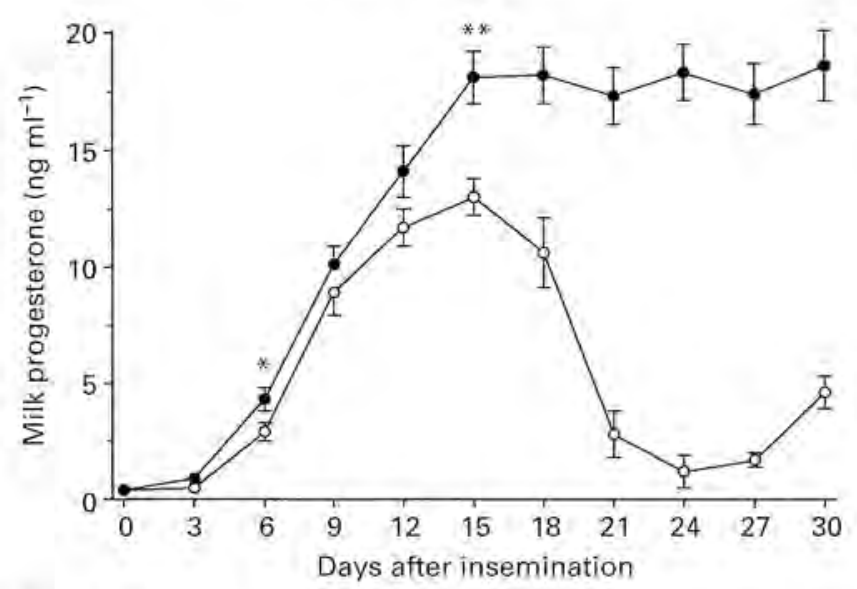

Fig. 1. Mean ( \pm SEM) milk progesterone concentration after insemination in cows that became pregnant $(\bullet n=28)$ and cows in which pregnancy failed $(0 ; n=24)$. Note the significant differences between pregnant and non-pregnant groups on day $15(P<0.01)$ and day $6(P<0.05) *{ }^{*} P<0.05 ; * P<0.01$. (Based on data from Mann et al, 1995).

Studies using recombinant bovine interferon $\alpha$, which has approximately $50 \%$ amino acid sequence identity with bovine interferon $\tau$, have demonstrated an extension of the duration of the cycle in cattle, but with associated adverse side effects such as hyperthermia, reduction in progesterone secretion and reduced conception rate (Plante et al., 1989, 1991; Barros et al., 1992). Highly purified bTP-1 obtained from culture of day 17-18 conceptuses (Helmer et al., 1989) and more recently recombinant bovine interferon $\tau$ (Meyer et al., 1995) have been shown to reduce luteolytic secretion of $\mathrm{PGF}_{2 \mathrm{c}}$ and extend luteal function in the cow, apparently without deleterious side effects.

\section{Timing and control of interferon $\tau$ production}

Expression of mRNA for interferon $\tau$ has been detected as early as day 12 in the cow, is maximal on days 15-16 and continues at least until day 25 (Farin et al., 1990). This expression appears to be limited to the trophectoderm and expression is not apparent in the endoderm or yolk sac (Farin et al., 1990). Despite the appearance of mRNA on day 12, we have found that significant quantities of interferon $\tau$ (as measured by antiviral assay) are first detected in uterine flushes between day 14 and day 16, when embryos have begun elongation (Fig. 2)

During the early stages of pregnancy, it is well established that progesterone stimulates the production of the endometrial secretions necessary for embryo development (for review see Geisert et al., 1992). The importance of the pattern of maternal progesterone in producing a suitable uterine environment for the embryo is demonstrated clearly by studies involving asynchronous embryo transfer. In such studies the uterus of a recipient ewe can, by prior treatment with progesterone, be rendered receptive to the transfer of an embryo from a donor ewe at a more advanced stage after mating (Lawson and Cahill, 1983). The effects of this progesterone include increased endometrial protein secretion (Garrett et al., 1988) and increased production of $\mathrm{PGE}_{2}$ (Vincent et al., 1986).

In cows, maternal concentrations of progesterone have a marked influence on the development of the embryo (Mann et al., 1996) and its ability to produce interferon $\tau$ (Mann et al., 1998). We found that cows with a late post-ovulatory increase in progesterone to lower luteal phase concentrations had embryos that, on day 16, exhibited little or no elongation and produced little or no interferon $\tau$. 


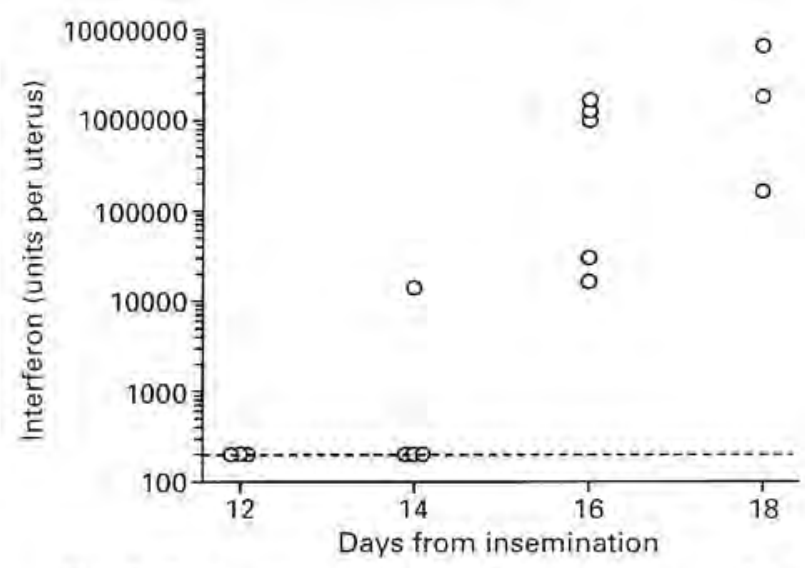

Fig. 2. Total uterine interferon- $t$ content measured in uterine flushings by antiviral assay in Holstein Friesian cows inseminated at natural oestrus and then slaughtered at various stages of early pregnancy. The dashed line represents the detection limit of the assay system. (GE Mann, unpublished).
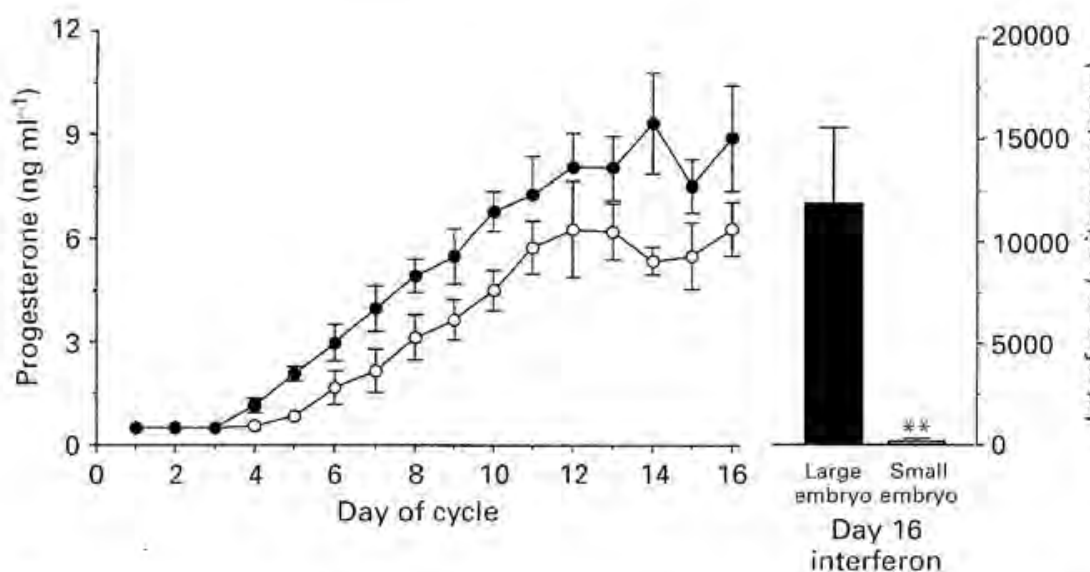

Fig. 3. Mean ( $($ SEM) plasma concentrations of progesterone in inseminated cows slaughtered on day 16 whose uteri were flushed to reveal either a large well-elongated embryo with a high concentration of interferon $\tau$ activity $(\bullet /$ bar $; n=5)$ or a small poorly developed embryo $(\% /$ bar; $n=5)$. Note both the delayed progesterone rise $(P<0.01)$ and low luteal phase concentrations $(P<0.05)$ leading to low interferon $\tau$ production $(P<0.01)$. ** $\mathrm{P}<0.01$. (Based on data from Mann et al., 1996, 1998)

Conversely day 16 embryos of cows with an earlier rise in progesterone to higher luteal phase concentrations were well elongated ( $>4 \mathrm{~cm}$ ) and produced large quantities of interferon- $\tau$ (Fig. 3).

A number of other studies have also suggested an important role for early luteal phase progesterone in the control of subsequent embryonic production of interferon- $\tau$. Nephew et al. (1991) demonstrated that ewes exhibiting a slightly higher plasma concentration of progesterone on days 2-4 of the luteal phase showed advanced embryo development on day 13 and an associated threefold increase in production of interferon $\tau$. Garrett et al. (1988) found that by increasing progesterone from days $2-5$ in cows, embryo development on day 14 was advanced significantly 
(tenfold increase in length of conceptus) and that production of proteins forming the "bovine trophoblast protein complex proposed to be involved with the maintenance of early corpus luteum function" (interferon $\tau$ ) was present in progesterone-treated cows but not in control cows. Kerbler et al. (1997) demonstrated only a slight increase in production of interferon $\tau$ by day 18 bovine embryos collected from cows with increased progesterone secretion from day 8 (caused by induction of accessory corpora lutea). These findings suggest that an early increase in progesterone is more important in stimulating embryo development and interferon $\tau$ synthesis than are later progesterone. concentrations. We have recently demonstrated that progesterone supplementation from day 5 to day 9 gives a significant increase in interferon $\tau$ production on day 16 compared with supplementation from day 12 to day 16 (Mann et al., 1998).

Although the maternal progesterone environment appears to have a major influence on the development of the early bovine embryo, and its ability to produce its antiluteolytic interferon $\tau$ signal, an understanding of how this is achieved requires an investigation of factors within the uterus. While a wide range of growth factors and cytokines are expressed by the endometrium and the embryo during early pregnancy and are probably involved to various degrees in the control of early embryo development (for review see Martal et al., 1997), little is known about the specific mechanisms controlling early embryo development and production of interferon $\tau$. Some factors that have been demonstrated to affect interferon $\tau$ production in sheep specifically include insulinlike growth factors -I and -II (Ko et al., 1991) granulocyte-macrophage-colony stimulating factor (Imakawa et al, 1993) and interleukin 3 (Imakawa et al., 1995). However, further research is required before any detailed control mechanisms can be elucidated.

\section{Development of the Luteolytic Mechanism - The Maternal Signal}

\section{Oxytocin receptor development and $P G F_{2 a}$ release}

In cattle, concentrations of endometrial oxytocin receptors are low or undetectable from about day $6-8$ of the luteal phase to immediately before luteolysis, about day $15-17$, when concentrations begin to increase (Meyer et al., 1988; Fuchs et al., 1990; Mann and Lamming, 1994). The pulsatile secretion of luteolytic $\mathrm{PGF}_{2 a}$ begins on about day 17 and is associated with a small rise in endometrial oxytocin receptor concentration (Mann and Lamming, 1993). By collection of repeated biopsy samples of uterine endometrium, we have found that oxytocin receptors, which are undetectable through much of the luteal phase $\left(<20 \mathrm{fmol} \mathrm{mg}^{-1}\right.$ protein), rise to a concentration of 121 $\pm 16 \mathrm{fmol} \mathrm{mg}^{-1}$ protein when large luteolytic episodes of $\mathrm{PGF}_{2 a}$ secretion are first observed. The onset of $\mathrm{PGF}_{2 \mathrm{a}}$ secretion is followed by luteolysis within $48 \mathrm{~h}$ and oxytocin receptor concentrations continue to increase to maximum concentrations of 500-1000 fmol mg ${ }^{-1}$ protein at oestrus (Fig. 4). Fuchs et al. (1990) found that oxytocin receptor concentrations on day 17, the anticipated start of luteolysis were about $10 \%$ of the values obtained on day 21 (the anticipated day of oestrus). Furthermore, Mirando et al. (1993) found a marked increase in oxytocin-induced PGF $_{2 \alpha}$ production in heifers between day 13 and day 16, despite only a slight increase in concentration of endometrial oxytocin receptors; a large increase in oxytocin receptor concentration did not occur until day 19. Thus luteolytic $\mathrm{PGF}_{2 \alpha}$ release requires only a modest increase in uterine oxytocin receptors. The peak concentrations of oxytocin receptor obtained at oestrus are associated with the fall in progesterone and increase in oestradiol secretion that occur as a result of luteolysis and are not, therefore, the cause of luteolysis.

Receptor localisation studies in ewes have established that this critical first increase in oxytocin receptor activity is restricted to the luminal epithelium; oxytocin receptors appear in the deeper tissues only after luteolysis starts (Wathes and Lamming, 1995). In cows oxytocin receptors first appear on the luminal epithelium of the uterine endometrium (Robinson et al., 1998a). This occurs at the same time as the uterus develops the ability to release $\mathrm{PGF}_{2 n}$ in response to oxytocin (Mann and Lamming, 1994). This finding demonstrates that in cows, as in ewes, it is the development of oxytocin receptors on the luminal epithelium that is the key event in the development of the 


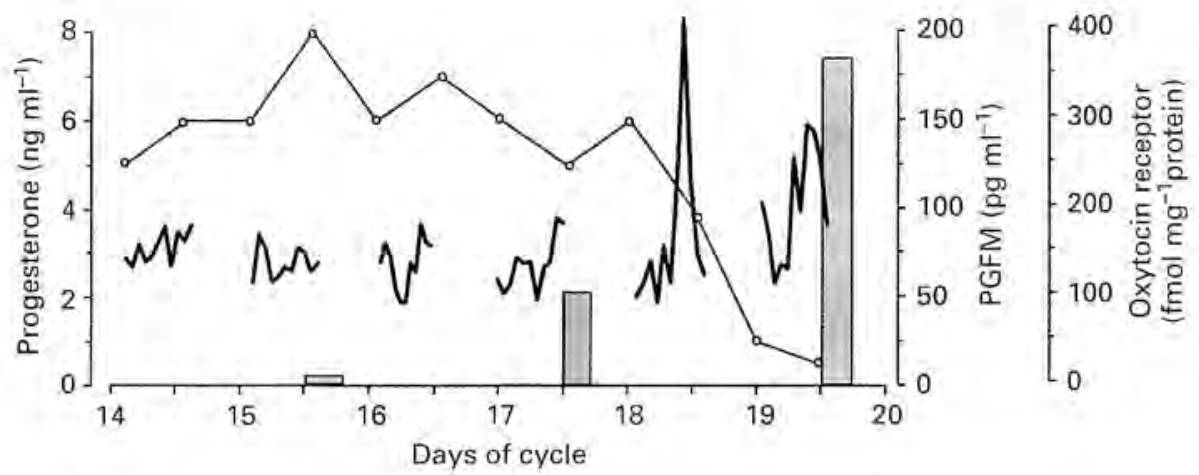

Fig. 4. Relationship between plasma progesterone concentration (0), endometrial oxytocin receptor concentration, measured in repeated endometrial biopsy samples (shaded bars) and plasma 13,14 dihydro-15-keto prostaglandin $\mathrm{F}_{20}$ (PGFM) concentrations (solid lines) during natural luteolysis in a typical Holstein Friesian cow. Note the small increase in oxytocin receptors needed to allow luteolytic $\mathrm{PGF}_{2 x}$ release and the subsequent further increase in receptor concentration once luteolysis had occurred (Based on data from Mam and Lamming, 1993)

luteolytic mechanism. Further support for this hypothesis, that changes in oxytocin receptor concentrations in the luminal epithelium are the critical factor, comes from the observation that most $\mathrm{PGF}_{2 \mathrm{~s}}$ release occurs from epithelium and not from stromal cells (Fortier et al., 1988). Thus the initiation of the luteolytic mechanism requires only a relatively small increase in endometrial oxytocin receptors and it is this initial increase in oxytocin receptor development within the luminal epithelium which the embryo must counteract if it is to prevent luteolysis.

Although many studies have investigated the importance of the oxytocin receptor in luteolysis, Kotwica et al. (1997) suggested that treatment of cows with an oxytocin antagonist does not prevent luteolytic $\mathrm{PGF}_{2 a}$ secretion. These results differ markedly from those in sheep where continuous infusion of a similar oxytocin antagonist completely blocked luteolytic PGF 2 secretion (Jenkin, 1992). While it is difficult to ignore the large body of evidence that supports a pivotal role for oxytocin induced $\mathrm{PGF}_{20}$ release in the luteolytic process in cows, the findings of Kotwica et al. (1997) do suggest that further evaluation of the mechanisms involved may be required.

\section{The role of steroid hormone receptors}

Receptor binding assays demonstrate that progesterone receptors are high at oestrus, increase further to about day 6-8 and then decline to low values by day 10-12 (Meyer et al., 1988). This pattern of expression is largely repeated in receptor localization studies (Boos et al., 1996; Robinson et al., 1998b). Progesterone inhibits the development of oxytocin receptors in ewes (Lau et al, 1992) and it has been postulated that this fall in the number of progesterone receptors is necessary to allow the development of oxytocin receptors needed to initiate the luteolytic mechanism (McCracken et al., 1984). By recreating cyclic changes in hormone concentrations in ovariectomized cows, we have demonstrated that during the luteal phase, progesterone initially inhibits oxytocin receptors (Lamming and Mann, 1995). However, by day 16, despite maintained progesterone concentrations, oxytocin receptors reappeared in the endometrium and their ability to release $\mathrm{PGF}_{2 \alpha}$ in response to oxytocin returned. Thus the hypothesis that after a suitable period progesterone loses its inhibitory action on the uterus allowing endometrial oxytocin receptor development and $\mathrm{PGF}_{20}$ release appears to be valid for cows as well as ewes.

In sheep, oestradiol receptors are undetectable during the mid-luteal phase owing to inhibition by progesterone. The receptors reappear at about the time of luteolysis and it has been suggested that an increase in oestrogen receptors is needed to allow oestradiol to stimulate the rise in oxytocin 
receptors needed for luteolysis (McCracken et al., 1984; Spencer et al., 1996). In cattle, receptor binding assays demonstrate peak concentrations of endometrial oestrogen receptor at oestrus and during the first few days of the luteal phase. Concentrations then tend to fall as the luteal phase progresses and an increase is observed as the cow approaches oestrus (Meyer et al, 1988). However, localization studies have shown that while this general pattern occurs in stromal tissues, and to some extent glandular tissues, in the luminal epithelium, the critical region in terms of luteolysis, fluctuating concentrations of oestrogen receptors are present throughout the ovarian cycle (Boos et al., 1996; Robinson et al., 1998b). These fluctuations appear to be correlated with fluctuations in plasma oestradiol (Robinson et al., 1998b). Thus it would appear that during the luteal phase of the cow the oestrogen receptor is not subjected to the same degree of downregulation as appears to be the case in the ewe. The presence of oestrogen receptors on the luminal epithelium during the entire luteal phase demonstrate that in cows, the initial upregulation of oxytocin receptor needed for the initiation of luteolysis is not controlled by the appearance of oestrogen receptors on the endometrium. This differs from current theories in the ewe in which the action of oestrogen on newly upregulated oestrogen receptors has been hypothesized as the trigger for the oxytocin receptor upregulation required for luteolysis (McCracken et al, 1984; Spencer et al., 1996).

The use of pharmacological doses of oestradiol has demonstrated the basic ability of oestradiol to upregulate endometrial oxytocin receptors (Hixon and Flint, 1987; Spencer et al., 1995). However, when postulating a role for upregulation of oxytocin receptors by oestrogen as the mechanism for the initiation of luteolysis, a number of results must be considered. Oxytocin receptor concentrations in the endometrium appear to increase independently of steroid hormones (Lamming and Mann, 1995). Furthermore, in ovariectomized ewes it has been shown that this oxytocin receptor upregulation is not attenuated by the use of passive immunization to neutralize any residual oestradiol that might be stimulating receptor development in ovariectomized animals (Payne et al., 1994). In many studies, no significant increase in peripheral oestradiol concentration has been observed before the initiation of luteolysis. However, Fogwell et al. (1985) did report an increase in oestradiol in utero-ovarian venous plasma before luteolysis and it is clear that oestradiol has an effect since luteolysis is prevented by the inhibition of oestradiol (Fogwell et al, 1985).

\section{Uterine Hormone Receptors During Early Pregnancy}

A number of studies in both cattle and sheep have demonstrated the general ability of the embryo itself, embryo-derived interferon $\tau$ or recombinant interferon $\tau$ to inhibit the development of oxytocin receptors on the endometrium. It is now generally accepted that this is the key event in the maintenance of pregnancy in both species. Elsewhere in this review the importance of the initial small rise in oxytocin receptors, localized to the luminal epithelium of the endometrium, in the initiation of luteolysis has been established. The inhibition of this initial rise in oxytocin receptors appears to be the key event in the establishment of pregnancy.

Fuchs et al. (1990) found that the presence of a viable conceptus in the uterus completely prevented both the small rise in oxytocin receptors in the uterus between day 14 and day 17 , and the much larger rise seen between days 17 and day 21 in cyclic cows. On day 16, a time at which the luteloytic mechanism is beginning to develop, oxytocin receptor mRNA was detectable in the luminal epithelium of over $40 \%$ of non-pregnant cows but was undetectable in all cows with an embryo (Robinson et al., 1998a).

In unilaterally pregnant sheep with transected uteri, development of oxytocin receptors is inhibited in the pregnant horn. However, in the non-pregnant horn, deprived of the usual fall in progesterone and rise in oestradiol after luteolysis, development of oxytocin receptors still occurs but is limited to the luminal epithelium (Lamming et al., 1995). Despite the presence of oxytocin receptors in only the luminal epithelium of the non-pregnant horn, large episodes of $\mathrm{PGF}_{2 \alpha}$ secretion could still be stimulated by the administration of oxytocin (Payne and Lamming, 1994). This finding raises the possibility that changes in receptors on the luminal epithelium may be all that is required for the development of an active luteolytic mechanism. Administration of oestradiol stimulates an 
increase in oxytocin receptors within $12 \mathrm{~h}$ of administration (Hixon and Flint, 1987) and thus within hours of the onset of luteolysis, endometrial hormone receptor changes occur that are the result of the post-luteolytic fall in progesterone and rise in oestradiol. Increases in receptors in regions other than the luminal epithelium, driven by changes in ovarian hormone secretion after luteolysis, are not required for the initiation of luteolysis. However, they may have a role in the final completion of the luteolytic process. As well as the effect of the post-luteolytic increase in oestradiol secretion on uterine hormone receptors, treatment with high concentrations of oestradiol has been shown to stimulate $\mathrm{PGF}_{20}$ secretion within $6 \mathrm{~h}$ of administration in cows (Knickerbocker et al., 1986).

We have recently investigated the effects of pregnancy on endometrial oxytocin, oestradiol and progesterone receptors on day 16 in non-pregnant cows and in cows with an embryo present in the uterus (Robinson et al, 1998a). In pregnant cows, there was a significant inhibition of both endometrial oxytocin receptor mRNA concentrations (Fig. 5a and Table 1) and oxytocin-induced secretion of $\mathrm{PGF}_{2 \alpha}$ (increased secretion in 6/15 cows with an embryo present compared with 14/14 non-pregnant cows). However, despite the inhibitory effect of the embryo on the initiation of a luteolytic mechanism, measurement of both oestradiol receptor mRNA and oestradiol receptor protein revealed no differences between pregnant and non-pregnant cows (Fig. 5b and Table 1). Thus it would appear that in cows, the embryo can inhibit both the initiation of oxytocin receptor and oxytocin-induced secretion of $\mathrm{PGF}_{2 \alpha}$ without affecting oestradiol receptor concentrations. As with the oestrogen receptor, progesterone receptors were also present at similar concentrations in both pregnant and non-pregnant cows in all regions of the uterus studied (Table 1), supporting the idea that changes in endometrial progesterone receptor concentrations are not involved in the inhibition of luteolysis during early pregnancy,

\section{Maternal Recognition of Pregnancy - Current Theories}

The principal role of the embryo during the maternal recognition of pregnancy is to inhibit the development of oxytocin receptors on the endometrium and hence the release of $\mathrm{PGF}_{2 n}$ that is responsible for the demise of the corpus luteum.

In cattle, as in sheep, the loss of progesterone receptors on the endometrium during the later stages of the luteal phase may prevent continued inhibition by progesterone of the development of oxytocin receptors. One mechanism by which the embryo could inhibit the development of oxytocin receptors on the endometrium could be through the maintenance of progesterone receptors. There is no evidence to suggest that this loss of progesterone receptors is prevented during pregnancy in the sheep (Spencer et al., 1996); similar results were obtained in cows (Robinson et. al., 1998a), in which concentrations of progesterone receptor were similar in pregnant and non-pregnant cows at the initiation of the luteolytic mechanism. A study in the rat has, for the first time, demonstrated a direct inhibitory effect of progesterone on the activity of the oxytocin receptor (Grazzini et al, 1998). Whether the embryo induces progesterone to exert a similar role in cows or sheep is not known.

In sheep, it has been postulated that interferon $\tau$ prevents the rise in endometrial oestrogen receptors that is thought to precede the rise in oxytocin receptors necessary for the induction of luteolytic release of $\mathrm{PGF}_{2 r i}$. This contention is supported by several studies. Spencer and Bazer (1995) demonstrated that while oestrogen receptor was present on the luminal epithelium on day 13 and 15 in cyclic ewes, it was absent in pregnant ewes at these times. In this study progesterone was lower on day 15 in the cyclic ewes, indicating that there is a rise in oestradiol secretion and consequent oestrogen upregulation of its own receptor in the different hormonal environment of the cyclic group. However, the difference in oestrogen receptor on day 13 does suggest a role for interferon- $\tau$ induced suppression of oestrogen receptor in the establishment of pregnancy in ewes. Furthermore, treatment of ewes with pharmacological concentrations of oestradiol to induce luteolysis induces oestrogen and oxytocin receptors, both of which can be inhibited by the concomitant administration of rolFN $\tau$ (Spencer et al., 1995). However, studies in cows indicate that the initial inhibition of oxytocin receptor development on the luminal epithelium and luteolytic uterine $\mathrm{PGF}_{2 \Omega}$ release occur in the absence of an effect on oestrogen receptor concentrations (Robinson et al, 1998a). 

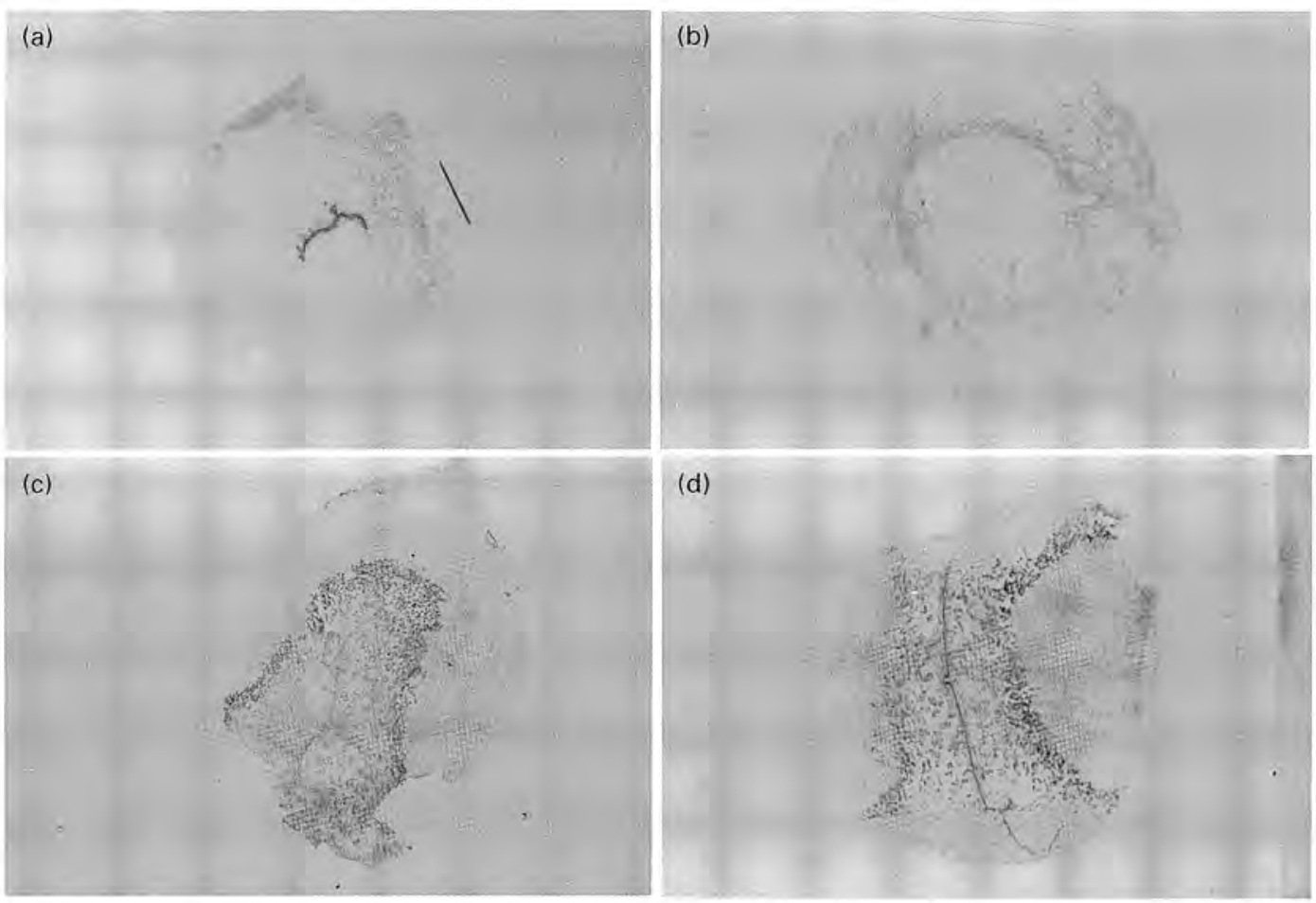

Fig. 5. In situ hybridization of day 16 bovine uterus showing the expression of (a) oxytocin receptor in the luminal epithelium of a non-pregnant cow, (b) lack of oxytocin receptor expression in a pregnant cow, (c) expression of oestrogen receptor in a non-pregnant cow and (d) expression of oestrogen receptor in a pregnant cow. Oxytocin receptor mRNA was expressed in the luminal epithelium of 6/14 non-pregnant compared with $0 / 15$ cows with an embryo present. Oestrogen receptor mRNA was expressed at a similar concentration in both the luminal epithelium and the deep glands of both pregnant and non-pregnant cows. Magnification $\times 5$. (Based on Robinson et al., 1998a.)

Table 1. The expression of oxytocin receptor, oestrogen receptor and progesterone receptor mRNA in the uterine endometrium of pregnant $(n=15)$ and non-pregnant $(n=14)$ cows on day 16 measured as absorbance units from autoradiographs.

\begin{tabular}{lllc}
\hline Receptor mRNA & \multicolumn{1}{c}{ Tissue } & Pregnant & Non-pregnant \\
\hline Oxytocin receptor & Luminal epithelium & nd $(<0.01)$ & $0.04 \pm 0.02^{*}$ \\
& Stroma & nd $(<0.01)$ & nd $(<0.01)$ \\
Oestradiol receptor & Luminal epithelium & $0.06 \pm 0.00$ & $0.07 \pm 0.01$ \\
& Superficial glands & $0.05 \pm 0.01$ & $0.06 \pm 0.01$ \\
Progesterone receptor & Deep glands & $0.13 \pm 0.01$ & $0.12 \pm 0.02$ \\
& Dense caruncular stroma & $0.03 \pm 0.01$ & $0.03 \pm 0.01$ \\
& Caruncular stroma & $0.08 \pm 0.02$ & $0.06 \pm 0.03$ \\
& Superficial glands & $0.02 \pm 0.00$ & $0.02 \pm 0.00$ \\
& Deep glands & $0.03 \pm 0.01$ & $0.02 \pm 0.00$ \\
\hline
\end{tabular}

Values are means \pm SEM.

*Expressed in 6/14 non-pregnant compared with 0/15 pregnant cows, $P<0.05$ (Chi squared test)

Data based on Robinson et al. (1998a). 
In addition to hypotheses based largely on changes in uterine hormone receptors, it is important to consider other aspects of the control of $\mathrm{PGF}_{2 \alpha}$ release. One such mechanism in cows involves the stimulation, by the embryo, of an endometrial inhibitor of $\mathrm{PGF}_{20}$ synthesis (Thatcher et al., 1995). In sheep, pregnancy is associated with a reduction in pulsatile release of $\mathrm{PGF}_{2 \alpha}$ coupled with an increased basal secretion, i.e. a change in the pattern and not the quantity of $\mathrm{PGF}_{2 \alpha}$ secretion (Payne and Lamming 1994). However, in cattle the attenuation of luteolytic episodes occurs in the absence of an increase in basal secretion of $\mathrm{PGF}_{2 \alpha}$ (Thatcher et al., 1995). This species difference is clearly supportive of the presence of a direct inhibitory effect of the embryo on $\mathrm{PGF}_{2 \alpha}$ secretion in cows.

\section{Conclusions}

The importance of the maternal progesterone profile in the control of the development of the embryo and its ability to produce the anti-luteolytic interferon $\tau$ signal has been established clearly. This is also the case for the role of interferon in the inhibition of endometrial oxytocin receptor upregulation and subsequent oxytocin-induced luteolytic PGF $_{2 \alpha}$ secretion and the induction of an inhibitor of $\mathrm{PGF}_{2 \alpha}$ synthesis. The lack of an effect of the embryo on oestrogen receptor concentrations at the critical initiation of luteolysis demonstrates a species difference between sheep and cows in the mechanism by which the embryo exerts an anti-luteolytic effect and the mechanism by which the embryo prevents oxytocin receptor development in cows remains to be established. In view of the critical role of the luminal epithelium in the luteolytic process, it is this region of the uterine endometrium in which the answers probably lie. However, before a mechanism of embryonic inhibition of oxytocin receptor upregulation can be deduced, the precise cause of the oxytocin receptor upregulation that the embryo must prevent must be determined. In establishing these mechanisms it will be important to discriminate between the specific small changes in the luminal epithelium that initiate luteolysis and the much larger changes in other regions of the endometrium that result from post-luteolytic changes in ovarian hormone secretion.

Many of the studies included in this review were funded by the Ministry of Agriculture Fisheries and Food and the Milk Development Council under the Link Sustainable Livestock Production Programme. This support is gratefully acknowledged.

\section{References}

Barros CM, Betts JG, Thatcher WW and Hansen PJ (1992a) Possible mechanisms for reduction of circulating concentrations of progesterone by interferon- ${ }_{\text {or }}$ in cows: effects on hyperthermia, Iuteal cells, metabolism of progesterone and secretion of LH Journal of Endocrinology 133 175-182

Boos A, Meyer W, Schwarz R and Grunert E (1996) Immunohistochemical assessment of oestrogen receptor and progesterone receptor distribution in biopsy samples of the bovine endometrium collected throughout the oestrous cycle Animal Reproduction Science 44 11-21

Farin CE, Imakawa K, Hansen TR, McDonnell JJ, Murphy CN, Farin PW and Roberts RM (1990) Expression of trophoblastic interferon genes in sheep and cattle Biology of Reproduction $43210-218$

Fogwell RL, Cowley JL, Wortman JA, Ames NK and Ireland JJ (1985) Luteal tunction in cows following destruction of ovarian follicles at mid cycle Theriogenology 23 389-398

Fortier MA, Guilbault LA and Grasso F (1988) Specific properties of epithelial and stromal cells from endometrium of cows Journal of Reproduction and Fertility $83239-248$

Fuchs AR, Behrens O, Helmer H, Liu C-H, Barros CM and Fields MJ (1990) Oxyfocin and vasopressin receptors in bovine endometrium and myometrium during the estrous cycle and early pregnancy Endocrinology 127 629-636

Garrett JE, Geisert RD, Zavy MT and Morgan GL (1988) Evidence for maternal regulation of early conceptus growth and development in beef cattle Journal of Reproduction and Eertility $84437-446$

Geisert RD, Morgan GL, Short EC and Zavy MT (1992) Endocrine events associated with endometrial function and conceptus development in cattle Reproduction Eertility and Development 4 301-305

Grazzini E, Guillon G, Mouillac B and Zingg HH (1998) Inhibition of oxytocin receptor function by direct binding of progesterone Nature 392 509-512

Gyawa P and Pope GS (1992) Oestradiol-17 $\beta$ in the milk of cows from 6 days before to 14 days after their insemination British Veterinary Journal 148 459-461

Helmer SD, Hansen PJ, Thatcher WW, Johnson JW and Bazer FW (1989) Intrauterine infusion of highly enriched bovine trophoblast protein-1 complex exerts an antiluteolytic effect to extend corpus luteum life span in cyclic cattle Joumal of Reproduction and Fertility 87 89-101

Henricks DM, Lamond DR, Hill JR and Dickey IF (1971) Plasma 
progesterone concentrations before mating and in early pregnancy in the beef heifer lournal of Animal Science 33 $450-454$

Hixon JE and Flint APF (1987) Effects of a luteolytic dose of oestradiol benzoate on uterine oxytocin receptor concentrations, phosphoinositide humover and prostaglandin $\mathrm{F}_{3 .}$ secretion in sheep Jourual of Reproduction and Fertility $79457-467$

Imakawa K, Helmer SD, Nephew KP, Meka CSR and Christenson RK (1993) A novel role for GM-CSF: enhancement of pregnancy specitic interferon production, ovine trophoblast protein-1 Endocrinology 132 1869-1871

Imakawa K, Tamura K, McGuire WJ, Khan S, Harbison LA, Stanga IP, Helmer SD and Christenson RK (1995) Effect of interleukin- 3 on ovine trophoblast interferon during early conceptus development Endocrine 3 511-517

Jenkin G (1992) Oxytocin and prostaglandin interactions in pregnancy and at parturition Journal of Reproduction and Fertility Supplement 45 97-111

Kerbler TL, Buhr MM, Jordan LT, Leslie KE and Walton JS (1997) Relationship between maternal plasma progesterone concentration and interferon- $\tau$ synthesis by the conceptus in cattle Theriogenology 47 703-714

Knickerbocker JJ, Thatcher WW, Foster DB, Wolfenson D, Bartol FF and Caton D (1986) Uterine prostaglandin and blood flow responses to estradiol-17ק in cyclic cattle Prosfaglandints 31 $757-775$

Ko $Y$, Lee CY, Ott TL, Davis MA, Simmen RCM, Bazer FW and Simmen FA (1991) Insulin-like growth factors in sheep uterine fluids: concentrations and relationship to ovine trophoblast protein-1 production during early pregnancy Biology of Reproduction $45135-142$

Kotwica J, Skarzynski D, Bogacki M, Merlin P and Starostka B (1997) The use of an oxytocin antagonist to study the function of ovarian oxytocin during Juteolysis in cattle Theriogenology 48 1287-1299

Lamming GE and Darwash AO (1995) Effect of inter-luteal interval on subsequent luteal phase length and fertility in post partum dairy cows Biology of Reproduction 53 (Supplement 1) Abstract 63

Lamming GE and Mann GE (1995) Control of endometrial oxytocin receptors and prostaglandin $F_{3 \mu}$ responses to oxytocin in ovariectomized cows by progesterone and estradiol Joumal of Reproduction and Fertility 103 69-73

Lamming GE, Darwash AO and Back HL (1989) Corpus luteum function in dairy cows and embryo mortality Journal of Reproduction and Fertility Supplement 37 245-252

Lamming GE, Wathes DC, Flint APF, Payne JH, Stevenson KR and Vallet JL (1995) Local action of trophoblast interferon in suppression of the development of oxytocin and oestradiol receptors in ovine endometrium joumal of Reproduction and Fertility 105 165-175

Lau TM, Gow GB and Fairclough RJ (1992) Differential effects of progesterone treatment on the oxytocin-induced prostaglandin $F_{2 u}$ response and the levels of endometrial oxytocin receptors in ovariectomised ewes Biology of Reproduction 46 17-22

Lawson RAS and Cahill LP (1983) Modification of embryo maternal relationships in ewes by progesterone treatment early in the oestrous cycle fournal of Reproduction and Fertility 67 473-475

Lukaszewska J and Hansel W (1980) Corpus luteum maintenance during early pregnancy in the cow Journal of Reproduction and Fertility 59485-493
McCracken JA, Schramm W and Okulicz WC (1984) Hormone receptor control of pulsatile secretion of $\mathrm{PGF}_{34}$ from the uterus and its abrogation in early pregnancy Animal Reproduction Sciente 7 31-55

Mann GE and Lamming GE (1993) Monitoring endometrial oxytocin receptor development in the cow using a biopsy technique Journal of Reproduction and Fertility Abstract Serics 11 Abstract 172

Mann GE and Lamming GE (1994) Use of repeated biopsies to monitor endometrial oxytocin receptors in cows Veteriuary Record $135403-405$

Mann GE and Lamming GE (1995a) Progesterone inhibition of the development of the luteolytic signal in the cow loumal of Reproduction and Feriility 104 1-5

Mann GE and Lamming GE (1995b) Effect of the level of oestradiol on oxytocin-induced prostaglandin $\mathrm{F}_{\mathrm{yi}}$ release in the cow Journal of Endocrinology 145 175-180

Mann GE, Lamming GE and Fray MD (1995) Plasma cestradiol during early pregnancy in the cow and the effects of treatment with buserelin Animal Reproduction Science 37 121-131

Mann GE, Mann SJ and Lamming GE (1996) The inter-relationship between the maternal hormone environment and the embryo during the early stages of pregnancy. lournal of Roproduction and Fertility Absiract Series 17 Abstract 55

Mann GE, Lamming GE and Fisher PA (1998) Progesterone control of embryonic interferon- $\tau$ production during early pregnancy in the cow Joumal of Reproduction and Feritity Abstract Series 21 Abstract 37

Martal J, Chene N, Camous S, Huynh L, Lantier E, Hermier P, L'Haridon R, Charpigny G, Charlier M and Chaouat G (1997) Recent developments and potentialities for reducing embryo mortality in ruminants: the role of IFN- $\tau$ and other cytokines in early pregnancy Reproduction. Fertility and Developnient 9 355-380

Meyer HHD, Mittermeier I and Schams D (1988) Dynamies of oxytocin, estrogen and progestin receptors in the bovine endometrium during the estrous cycle Acta Endocrinologica 118 96-104

Meyer MD, Hansen PJ, Thatcher WW, Drost M, Badinga L, Roberts RM, Li J, Ott TL and Bazer FW (1995) Extension of corpus luteum life span and reduction of uterine secretion of prostaglandin $\mathrm{F}_{3 n}$ of cows in response to recombinant interferon - $\tau$ lournal of Dairy Science 78 1921-1931

Mirando MA, Willard CB and Whiteaker SS (1993) Relationships among endometrial oxytocin receptors, oxytocin stimulated phosphinosotide hydrolysis and prostaglandin $\mathrm{F}_{3 u}$ secretion in vitro, and plasma concentrations of ovarian steroids before and during corpus luteum regression in cyclic heifers Biology of Reproducfion 48 874-882

Moor RM and Rowson LEA (1966) The corpus luteum of the sheep: effect of the removal of embryos on luteal function Journal of Endocrinology 34 497-502

Nephew KP, McClure KE, Ott T, Budois DH, Bazer FW and Pope WF (1991) Relationship between variation in conceptus development and differences in estrous cycle duration in ewes Biology of Reproduction 44 536-539

Northey DL and French LR (1980) Effect of embryo removal and intrauterine infusion of embryonic homogenates on the life span of the bovine corpus luteum Jotimal of Animal Science 50 298-302

Payne JH and Lamming GE (1994) The direct influence of the embryo on uterine $\mathrm{PGF}_{2 \alpha}$ and $\mathrm{PGE}_{2}$ production in sheep Journal of Reproduction and Eertility 101 737-741 
Payne JH, Mann GE and Lamming GE (1994) Progesterone action in ovariectomised ewes passively immunised against oestradiol fournal of Reproduction and Fertility Abstract Series 14 Abstract 70

Plante C, Hansen PJ, Martinod S, Siegenthaler B, Thatcher WW Pollard JW and Leslie MV (1989) Effect of intramuscular administration of interferon- ${ }_{n 1}$ on luteal life span in cattle Journal of Dairy Science 72 1859-1865

Plante C, Thatcher WW and Hansen PJ (1991) Alteration of oestrous cycle length, ovarian function and oxytocininduced release of prostaglandin $\mathrm{F}_{2 a}$ by intrauterine and intramuscular administration of recombinant interferon- $\alpha$ to cows Journal of Reproduction and Fertility 93 375-384

Pritchard JY, Schrick FN and Inskeep EK (1994) Relationship of pregnancy rate to peripheral concentrations of progesterone and oestradiol in beef cows Theriogenology 42 247-259

Robinson RS, Mann GE, Lamming GE and Wathes DC (1998a) The effect of pregnancy on the expression of uterine oxytocin, oestrogen and progesterone receptors during early pregnancy in the cow Journal of Endocrinology 160 21-33

Robinson RS, Mann GE, Lamming GE and Wathes DC (1998b) Oxytocin, oestrogen and progesterone receptor mRNA expression in the bovine endometrium throughout the oestrous cycle Journal of Reproduction and Fertility Abstract Series 21 Abstract 97
Rowson LEA and Moor RM (1967) The influence of embryonic tissue homogenate infused into the uterus and life-span of the corpus luteum in the sheep lournal of Reproduction and Fertility 13 511-516

Spencer TE and Bazer FW (1995) Temporal and spatial alterations in uterine estrogen receptor and progesterone receptor gene expression during the estrous cycle and early pregnancy in the ewe Biology of Reproduction 53 1527-1543

Spencer TE, Becker WC, George P, Mirando MA, Ogle TF and Bazer FW (1995) Ovine interferon- $\tau$ (IFN- $\tau$ ) inhibits estrogen receptor up-regulation and estrogen-induced luteolysis in cyclic ewes Endocrinology $1364932-4944$

Spencer TE, Ott TL and Bazer FW (1996) $\tau$ - interferon: pregnancy recognition signal in ruminants Proceedings of Experimental Biology and Medicine 213 215-229

Thatcher WW, Meyer MD and Danet-Desnoyers G (1995) Matemal recognition of pregnancy Journal of Reproduction and Fertility Supplement 49 15-28

Vincent DL, Meredith S and Inskeep EK (1986) Advancement of uterine secretion of prostaglandin F2 by treatment with progesterone and transfer of asynchronous embryos Endocrinology 119 527-529

Wathes DC and Lamming GE (1995) The oxytocin receptor, luteolysis and the maintenance of pregnancy Jounul of Reproduction and Fertility Supplement 49 53-67 